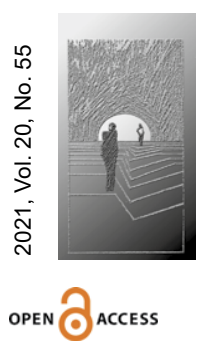

Katarzyna Stadnik

ORCID: https://orcid.org/0000-0002-9771-3677

UMCS w Lublinie

katarzyna.stadnik@mail.umcs.pl

DOI: 10.35765/hw.2112

\title{
Metafory pojęciowe dotyczące zdrowia psychicznego w trakcie pandemii COVID-19 w Polsce
}

\section{STRESZCZENIE:}

CEL NAUKOWY: Celem artykułu jest analiza wypowiedzi psychologów i psychiatrów w wywiadach opublikowanych w prasie i/lub portalach internetowych, dotyczących wyzwań, jakie dla równowagi psychicznej stanowi codzienność pandemii COVID-19 w Polsce.

PROBLEM I METODY BADAWCZE: Artykuł wypełnia lukę w badaniach dyskursu publicznego odnośnie do zdrowia psychicznego podczas epidemii wywołanej przez wirus SARS-CoV-2, przyjmując założenia teoretyczne i metodologiczne językoznawstwa kognitywnego, zgodnie z którymi metafora manifestująca się w języku ma w istocie naturę pojęciową.

PROCES WYWODU: Przedmiotem badania są metafory pojęciowe używane przez psychologów i psychiatrów w komunikowaniu wiedzy eksperckiej w dyskursie publicznym. Artykuł rozpatruje tę kwestię w kontekście rozwijania kompetencji zdrowotnych społeczeństwa w celu przeciwdziałania zaburzeniom psychicznym wywołanym przez pandemię.

WYNIKI ANALIZY NAUKOWEJ: Wyniki analizy wskazują, że trafnie dobrane metafory usprawniają proces wnioskowania na temat relacji przyczynowo-skutkowych pomiędzy zaistnieniem sytuacji epidemicznej a wystąpieniem zaburzeń psychicznych w różnych grupach wiekowych społeczeństwa polskiego.

WNIOSKI, INNOWACJE, REKOMENDACJE: Wyniki bieżącej analizy mogą stanowić podstawę do dalszych badań na temat kognitywnych podstaw skutecznych sposobów popularyzacji wiedzy eksperckiej o zdrowiu psychicznym, ze szczególnym uwzględnieniem tych obszarów codzienności epidemicznej, które mogą łatwo podlegać dezinformacji.

$\rightarrow$ SŁOWA KLUCZOWE: METAFORA POJĘCIOWA, KOMPETENCJE ZDROWOTNE, PANDEMIA COVID-19, RAMOWANIE METAFORYCZNE, ZDROWIE PSYCHICZNE 


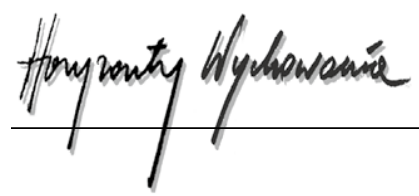

ABSTRACT

Conceptual Metaphors Related to Mental Health During the COVID-19 Pandemic in Poland

RESEARCH OBJECTIVE: The aim of the paper is to analyse linguistic data from a public discourse on mental health during the COVID-19 pandemic. The data come from interviews concluded with psychologists/psychiatrists, published in newspapers/magazines or online.

THE RESEARCH PROBLEM AND METHODS: The article fills a gap in public discourse research on mental health during the SARS-CoV-2 virus epidemic by adopting the theoretical and methodological assumptions of cognitive linguistics that the metaphor manifested in language is essentially conceptual in nature.

THE PROCESS OF ARGUMENTATION: The subject of the research are conceptual metaphors used by psychologists and psychiatrists in communicating expert knowledge in the public discourse. The article examines this issue in the context of developing the health competences of the society in order to counteract mental disorders caused by the pandemic.

RESEARCH RESULTS: The results of the analysis indicate that correctly selected metaphors facilitates the process of drawing inference about the cause-effect relations between the occurrence of an epidemic situation and the occurrence of mental disorders in various age groups of Polish society.

CONCLUSIONS, INNOVATIONS, AND RECOMMENDATIONS: The results of the current analysis can form the basis for further research on the cognitive foundations of effective ways of disseminating the expert knowledge about mental health, with particular consideration placed on those areas of epidemic daily life that can be easily disinformed.

\section{$\rightarrow$ KEYWORDS: CONCEPTUAL METAPHOR, COVID-19 PANDEMIC, HEALTH}

LITERACY, MENTAL HEALTH, METAPHORICAL FRAMING

\section{Wstęp}

Pandemia COVID-19 stanowi wyzwanie dla zdrowia psychicznego. Dla wielu osób wiąże się z przewlekłym stresem, wywołanym między innymi przez niebezpieczeństwo utraty życia i zdrowia, trudności ekonomiczne, ograniczenie kontaktów społecznych. Dla pewnej grupy osób postrzeganie wspomnianych stresorów może prowadzić do nasilenia objawów depresji oraz odczuwanego lęku (Gambin, 2021). Brak poczucia bezpieczeństwa pogłębia infodemia, przejawiająca się w szerzeniu zniekształconych informacji na temat epidemii wywołanej przez wirusa SARS-CoV-2. Osoby podatne na dezinformację nierzadko odrzucają naukowe wyjaśnienia dotyczące epidemii i/lub nie podejmują działań zmierzających do zwalczenia związanych z epidemią zagrożeń. Badania pokazują, że społeczeństwo polskie nie jest wolne od tego problemu (Gambin, 2021). 
Jedną z wielu możliwych przyczyn zniekształconej percepcji zagrożeń wywołanych przez pandemię jest sposób, w jaki w dyskursie publicznym przedstawia się chorobę COVID-19 oraz pandemię i jej skutki dla zdrowia psychicznego. Podkreśla się zatem znaczenie dostępu do wiarygodnej informacji oraz rolę naukowców, zwłaszcza ekspertów w zakresie psychologii i psychiatrii, w jej rozpowszechnianiu (Doroszewska i in., 2020). Jak pisze Heitzman, istotny jest umiejętny przekaz wiedzy naukowej w sposób „zrozumiały dla każdego. Zadaniem psychiatrów i psychologów w czasie epidemii jest dostosowanie i uzupełnianie formy przekazu informacji do możliwości percepcji odbiorców" (2020, s. 197). Wypowiadając się publicznie, specjaliści mogą przyczynić się do rozwoju kompetencji zdrowotnych społeczeństwa, tj. umiejętności poznawczych i społecznych sprawiających, że jednostka potrafi pozyskiwać informacje na temat zdrowia, rozumie je i umiejętnie wykorzystuje w sferze dobrostanu fizycznego, jak i psychicznego (Nutbeam, 1998).

Metafora jest jednym z narzędzi objaśniania i rozpowszechniania wiedzy specjalistycznej. W językoznawstwie kognitywnym uznaje się ją za zjawisko o wymiarze zarówno językowym, jak i poznawczym. Metafora pomaga uprościć złożony problem poprzez uwydatnienie pewnych jego aspektów i usunięcie innych na dalszy plan. Służy temu ramowanie metaforyczne, któremu najczęściej podlegają pojęcia abstrakcyjne (np. pandemia, zdrowie/zaburzenia psychiczne) ${ }^{1}$. Zdaniem Jaspala i Nerlich (2020) dzięki ramowaniu metaforycznemu pandemii COVID-19 powstają różne reprezentacje społeczne tego zjawiska, czyli „zestaw[y] wzajemnie powiązanych pojęć i definicji codziennego świata” (Zbróg i Zbróg, 2016, s. 15). Chętniej akceptowane są w społeczeństwie reprezentacje popularyzowane przez naukowców niż na przykład polityków (Jaspal i Nerlich, 2020).

Ramowanie metaforyczne stosowane przez ekspertów w dyskursie publicznym może pomóc w rozwijaniu kompetencji zdrowotnych społeczeństwa odnośnie do pandemii COVID-19 i jej wpływu na dobrostan psychiczny człowieka. Nie istnieje jeden sposób ramowania jednakowo skuteczny względem różnych aspektów bieżącej sytuacji epidemicznej (Wicke i Bolognesi, 2020). Pojawia się pytanie, które z metafor konceptualnych używanych przez ekspertów w ich wypowiedziach odnośnie do wpływu pandemii SARS-CoV-2 na dobrostan psychiczny człowieka mogą stanowić skuteczne narzędzia popularyzowania wiedzy specjalistycznej w polskim społeczeństwie. Analiza takich metafor w niniejszym artykule ma na celu wyjaśnienie, w jaki sposób efekty ramowania związane z ich wykorzystaniem w dyskursie publicznym mogą sprzyjać poprawie kompetencji zdrowotnych społeczeństwa polskiego w zakresie zdrowia psychicznego.

\section{Metody i narzędzia badawcze}

W artykule przyjęto perspektywę teoretyczną i metodologiczną językoznawstwa kognitywnego, którego główna teza podkreśla ucieleśniony charakter procesów poznawczych

${ }^{1} \mathrm{~W}$ artykule metafory konceptualne oraz związane $\mathrm{z}$ nimi schematy wyobrażeniowe zapisano kursywą. 


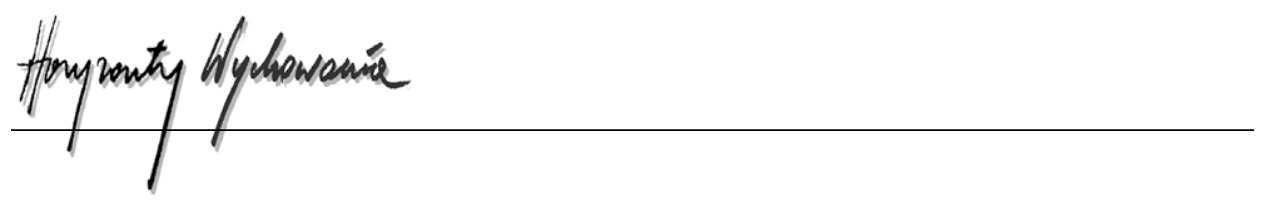

(Evans, 2007). Metafory w języku (metafory językowe) wyrażają pewne konceptualizacje (metafory pojęciowe). Metafora powstaje w wyniku nadawania struktury jednej docelowej domenie pojęciowej poprzez rzutowanie na nią struktury domeny źródłowej (Evans, 2007, s. 67). Dzięki zbiorowi odwzorowań pomiędzy obiema domenami użytkownik języka może wnioskować na temat domeny docelowej, wykorzystując wiedzę odnoszącą się do domeny źródłowej.

Ramowanie metaforyczne związane jest z aktywowaniem ram pojęciowych, reprezentacji zawierających uogólnioną wiedzę o doświadczeniu ucieleśnionym jednostki. Oprócz wiedzy potocznej, dotyczącej sytuacji typowych w danej kulturze, ramy mogą reprezentować wiedzę specjalistyczną. Wybór domeny źródłowej opartej na modelu reprezentującym wiedzę potoczną może oznaczać odmienny sposób ramowania określonej domeny docelowej od ramowania odwołującego się do wiedzy specjalistycznej (Kövecses, 2011).

Kwestia metafory w dyskursie zdrowotnym podejmowana była wielokrotnie. Przykładowo Wallis i Nerlich (2005) analizują system metafor epidemii SARS w 2003 roku w brytyjskim dyskursie prasowym. Wykazują, że metafora zabójcy podkreśla wpływ zakażenia na chorego, metafory kontroli zwracają uwagę czytelnika na to, jakie działania podjęto w odpowiedzi na rozprzestrzenianie się wirusa (Wallis i Nerlich, 2005, s. 2632). System metafor dla SARS okazał się uboższy w treści społeczno-kulturowe w porównaniu z metaforami HIVIAIDS (np. AIDS to grzech) (Wallis i Nerlich, 2005; zob. też Craig, 2020). Nie wszystkie metafory są równie trafne, co zmniejsza ich skuteczność jako narzędzi konstruowania konceptualizacji problemów zdrowia fizycznego (zob. Demjén i Semino, 2016) i psychicznego (zob. Tay, 2016). Stopień trafności metafory, który może wpływać na sposób rozumowania i formułowania wniosków odnośnie do rozpatrywanego problemu, zależy od tego, czy i w jaki sposób odwołuje się ona do ucieleśnionego, usytuowanego kulturowo doświadczenia, tworzącego fundament porozumienia między członkami wspólnoty językowej (Thibodeau i in., 2017; zob. też Semino, 2021, s. 54).

Dostępne publikacje naukowe o metaforyce pandemii COVID-19 w Polsce (np. Krawczyk-Wasilewska, 2020; Makowska, 2021; Wojtukiewicz, 2020) nie dotyczą ramowania metaforycznego zdrowia psychicznego podczas epidemii w kraju ani kwestii rozwijania kompetencji zdrowotnych polskiego społeczeństwa. Bieżące badanie ma charakter jakościowy, zmierzając do lepszego zrozumienia problemu, który nie został jeszcze dobrze rozpoznany. Metafory na poziomie pojęciowym można identyfikować poprzez analizę metafor w języku. Obecnie standardową procedurą używaną w tym celu jest MIP (ang. Metaphor Identification Procedure) grupy Pragglejaz (Gibbs, 2017, s. 69-77), którą wykorzystano także w niniejszym badaniu. Jako kryterium doboru danych językowych wybrano gatunek wywiadu (uwzględniono 31 wywiadów). Rozmowy opublikowano w prasie i/lub na portalach internetowych w okresie od marca 2020 do czerwca 2021 roku (wykaz zastosowanych źródeł znajduje się bibliografii). Wśród rozmówców znajdowali się psychologowie, psychiatrzy oraz specjaliści z zakresu psychologii dziecięcej, psychotraumatologii, psychoterapii, psychiatrii dzieci i młodzieży. Próba nie jest reprezentatywna. Liczba wypowiadających się specjalistów ogranicza się bowiem do 
grupy osób, które zgodziły się wziąć udział w rozmowie z dziennikarzami. Ze względu na potrzeby analizy odwołania do danych językowych uporządkowano według daty publikacji każdego z wywiadów. Umożliwia to prześledzenie zmian w konceptualizacjach metaforycznych, jakie zachodziły w trakcie rozwoju pandemii COVID-19 w Polsce.

\section{Wybrane metafory pojęciowe dotyczące zdrowia psychicznego podczas pandemii COVID-19 w Polsce}

Dane wskazują na pewną schematyczną strukturę wywiadów. W pierwszej kolejności eksperci koncentrowali się na przedstawieniu pandemii jako źródła zagrożeń dla dobrostanu psychicznego człowieka oraz omówieniu wywołanych sytuacją epidemiczną zaburzeń psychicznych, aby następnie wyjaśnić metody przeciwdziałania tym problemom. $\mathrm{Na}$ tej podstawie wyróżniono trzy kategorie metafor.

\subsection{Metafory pojęciowe PANDEMII}

Wyodrębniono następujące domeny docelowe, służące ramowaniu metaforycznemu abstrakcyjnego pojęcia pandemii/epidemii: przeszkoda (20.03.2020), brak równowagi (20.03.2020, 30.01.2021), przejazd przez ciemny tunel (23.03.2020), ograniczenie fizyczne (23.03.2020), osoba, odbierająca nam wartościowe rzeczy (02.04.2020), trauma (20.03.2020, 02.04.2020, 14.12.2020, 28.03.2021, 31.05.2021), wróg (02.04.2020, 22.02.2021), przeciwsiła (15.05.2020), odłączenie (28.05.2020, 04.03.2021), maraton (01.12.2020), brak podparcia (28.12.2020), przerwanie łączności z innymi (28.12.2020), siła destrukcyjna (04.03.2021).

\subsection{Metafory pojęciowe dotyczące zaburzeń psychicznych wywołanych sytuacją epidemiczną}

Do drugiej kategorii należą następujące metafory: złość/agresja to nadmiar substancji wypełniającej pojemnik na emocje, bazująca na metaforze ludzkie ciało to pojemnik na emocje (19.03.2020), zdrowie psychiczne i fizyczne człowieka to integralna całość lub emocje $i$ ciało to jedność (20.03.2020, 17.04.2020, 26.03.2021), trauma to zwierzę, które można oswoić (02.04.2020), zaburzenia psychiczne to tsunami/wzbierająca fala (06.04.2020, 17.04.2020, 07.05.2021, 24.05.2021), kryzys psychiczny to pozostawanie w stanie braku równowagi (15.05.2020, 18.01.2021, 02.04.2021), stygmatyzacja zaburzeń psychicznych to tworzenie barier (28.05.2020, 24.03.2021), negatywne emocje to toksyna/trucizna (28.12.2020), psychika człowieka to maszyna potrzebująca energii/paliwa (26.10.2020, 19.01.2021), zaburzenia emocjonalne to nadmierny wydatek (energii/paliwa) $(26.10 .2020,19.01 .2021)$, dbanie o swój dobrostan psychiczny to 


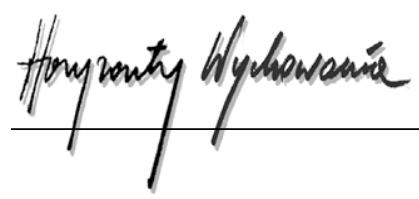

reparenting (bycie rodzicem dla samego siebie) (26.10.2020), stres to obciążenie/ciężar (19.01.2021), dystres to nadmiar substancji w pojemniku, bazująca na metaforze ludzkie ciało to pojemnik na emocje (17.03.2021).

Odrębną grupę stanowią metafory zdrowia psychicznego dzieci/młodzieży podczas pandemii: dysfunkcje w rodzinach to zaburzenie równowagi (15.02.2020), złe doświadczenia to przedmioty przekazywane dzieciom przez rodziców/dziadków (14.12.2020, 26.03.2021), depresja dzieci/nastolatków to wzbierająca fala (26.03.2021), psychika dziecka to kruchy przedmiot oraz patologie rodzinne to siła niszcząca psychikę dziecka (29.04.2021).

\subsection{Metafory sposobów przeciwdziałania zaburzeniom psychicznym w czasie pandemii}

Odwoływano się do następujących metafor pojęciowych zdrowia psychicznego/problemów psychicznych: dojrzałość psychiczna to umiejętność pokonywania przeszkód (20.03.2020, 22.06.2020), psychoterapia to tarcza obronna (02.04.2020), pandemia to lekcja/okazja do uczenia się czegoś nowego (25.03.2020, 17.04.2020, 28.05.2020), zdrowie psychiczne to aktywność/działanie (19.03.2020, 20.03.2020, 23.03.2020, 22.06.2020, 02.03.2021, 17.03.2021), natura to lek na zmartwienia/opiekun (20.11.2020, 22.02.2021), zdrowie psychiczne to uważność/umiejętność uważnego obserwowania rzeczywistości (26.10.2020, 22.02.2021), zapobieganie zaburzeniom psychicznym to zachowanie kontaktu (17.03.2021, 02.03.2021,04.03.2021), przy czym w ostatniej metaforze domeną źródłową jest domena ucieleśnionej interakcji ze światem fizycznym i społecznym.

Odnośnie do ochrony zdrowia psychicznego dzieci/młodzieży zidentyfikowano następujące metafory: odzyskiwanie zdrowia psychicznego przez młodego człowieka to nabywanie mechanizmów obronnych (26.03.2021), leczenie psychiatryczne dzieci to pokonywanie dystansu/drogi (24.03.2021, 02.06.2021).

\section{Wyniki analizy}

Nie jest możliwe dogłębne przeanalizowanie wszystkich zidentyfikowanych metafor ze względu na ograniczoną objętość artykułu. W poniższej dyskusji omówiono grupę wybranych metafor i problemów wynikających z zastosowanych sposobów ramowania kwestii zaburzeń psychicznych. Analiza językoznawczo-kognitywna, na podstawie której wyodrębniono trzy grupy metafor, pokazała, że wiele z nich odwołuje się nie do ram, lecz do bardziej podstawowych reprezentacji, tzw. schematów wyobrażeniowych, ubogich w szczegóły i pozbawionych informacji nacechowanych kulturowo. Należy do nich schemat pojemnika, siły, kontaktu, równowagi. Przykładowo, do owych metafor zaliczają się konceptualizacje pandemia to przeciwsiła, stres to ciężar czy ludzkie ciało to pojemnik na emocje. Eksperci podkreślali w ten sposób, jak fundamentalny jest charakter 
wywołanych epidemią zmian w ucieleśnionym doświadczaniu codzienności w polskim społeczeństwie. Dane pokazują, że schematy wyobrażeniowe motywują konceptualizację pandemii oraz jej następstw dla zdrowia psychicznego (podrozdziały 3.1, 3.2), ale są rzadkie w konceptualizacjach sposobów przeciwdziałania zaburzeniom psychicznym w czasie pandemii (podrozdział 3.3). To właśnie w tej ostatniej sferze specjaliści najczęściej wykorzystywali ramowanie metaforyczne w celu przybliżenia metod terapii zaburzeń psychicznych, co prawdopodobnie wynika ze społeczno-kulturowego uwarunkowania kompetencji zdrowotnych (np. dostępu do opieki zdrowotnej, edukacji, uwrażliwienia na język dyskursu publicznego na temat problemów psychicznych itd.).

Odnośnie do wykorzystywania ram pojęciowych z zakresu wiedzy specjalistycznej należy podkreślić, że jest ich niewiele, co prawdopodobnie wynika z większej użyteczności domen źródłowych znanych większości Polaków. Łatwo zauważyć, że liczba metafor objaśniających pandemię systematycznie malała, ponieważ społeczeństwo oswajało się stopniowo z zagrożeniem epidemicznym.

Konceptualizacją szczególną jest metafora pandemia to trauma, używana najczęściej i najdłużej przez specjalistów. Wydaje się, że takie ramowanie uznali oni za najbardziej trafne, pomimo wspomnianego oswojenia się społeczeństwa ze stanem epidemicznym. Powstaje pytanie, czym motywowany był ten wybór domeny źródłowej. Po pierwsze, skategoryzowanie reakcji psychicznych na wybuch pandemii jako traumy wynika z podobieństwa reakcji fizycznych i poznawczych na zagrożenie w obu wspomnianych przypadkach. Stanowi to podstawę systematycznych odwzorowań między domeną docelową, związaną z doświadczeniem pandemii a źródłową, która dotyczy doświadczenia traumy. Rozumowanie metaforyczne na podstawie tej metafory prowadzi do wniosku, że zaburzenia wywołane pandemią to stan wynikający z naturalnej reakcji człowieka na zagrożenie życia i zdrowia. To istotne spostrzeżenie, ponieważ problemy psychiczne bywają przyczyną stygmatyzacji jednostki jako niezdolnej do kontrolowania własnych emocji. Po drugie, aktywowanie pojęcia traumy uwypukla związek przyczynowy pomiędzy wywołującym traumę wydarzeniem a relatywnie trwałymi skutkami traumatycznego stresora. Powtarzanie się tej metafory w dyskursie w analizowanym okresie (marzec 2020 - czerwiec 2021) podkreśla więc konieczność pilnego przeciwdziałania problemom psychicznym szerzącym się w społeczeństwie. Wskazuje na to równoległe współistnienie w dyskursie publicznym metafor, takich jak zaburzenia psychiczne/depresja dzieci/ nastolatków to tsunami/wzbierająca fala lub negatywne emocje to toksyna/trucizna.

Problem kryzysu psychicznego w grupie wiekowej dzieci/młodzieży był głównym tematem rozmowy w 10 z 31 wywiadów. W przypadku ogólnej populacji specjaliści wielokrotnie dokonywali ramowania metaforycznego zdrowia psychicznego, aktywując konwencjonalne domeny źródłowe lekcji/okazji do rozwoju umiejętności, leku, aktywności fizycznej, interakcji społecznych. Jest to zapewne odpowiedź na ograniczenia o fizycznym charakterze, związane z izolacją społeczną. Można wspomnieć o bardziej idiosynkratycznych konceptualizacjach, takich jak zdrowie psychiczne to uważność, które trudno jednak uznać za trafne w odniesieniu do zdolności poznawczych dzieci. Zwraca uwagę niewielka liczba metafor dotyczących pomocy psychologicznej/psychiatrycznej 


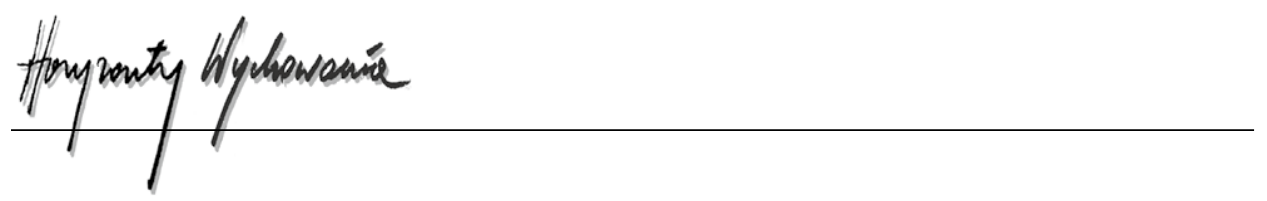

dla najmłodszej grupy wiekowej. W wielu wywiadach specjaliści przedstawiali zagadnienie zaburzeń psychicznych u młodych osób w kontekście kryzysu psychiatrii dziecięcej i trwającej reformy tego systemu, co mogło spowodować uwypuklenie problemów systemowych kosztem przesunięcia na dalszy plan kwestii indywidualnych zaburzeń.

\section{Wnioski}

Badanie miało na celu określenie, co wpływa na trafność metafor pojęciowych jako narzędzi transferu wiedzy służącej do podniesienia kompetencji społeczeństwa polskiego w zakresie zdrowia psychicznego w związku z zagrożeniami wywołanymi przez pandemię COVID-19. Zdaniem Gibbsa (2016) użycie metafory w dyskursie jest wypadkową oddziaływania wielu różnych czynników: ucieleśnienia, wpływu kontekstu społeczno-kulturowego, jak też idiosynkratyczności uczestnika dyskursu. Takie innowacyjne rozumienie metafory jako zjawiska dynamicznego nie jest obecnie szeroko rozpoznawane przez językoznawców kognitywnych. Wyniki analizy potwierdzają słuszność tego ujęcia metafor. Analizowane konceptualizacje metaforyczne były rozpatrywane między innymi w odniesieniu do innych metafor w dyskursie publicznym na temat zdrowia psychicznego. Wspólnie tworzą one sieć powiązań konceptualnych pomiędzy ramami, stanowiącą pewną porcję wiedzy pojęciowej, aktywowanej przez uczestników dyskursu publicznego w odniesieniu do kwestii zdrowia psychicznego.

Istotny jest nie tylko wybór pojedynczej metafory, która skutecznie ramuje daną wypowiedź, ale również fakt współistnienia w dyskursie publicznym wielu trafnych metafor, które pomagają jednostkom wnioskować na temat natury zagrożeń pandemicznych dla dobrostanu psychicznego. Określone ramowanie metaforyczne może występować w więcej niż jednym wywiadzie, ponieważ może posiadać różne manifestacje językowe. Wskazuje to na popularyzację pewnych konceptualizacji metaforycznych, motywujących reprezentacje społeczne pandemii COVID-19; jest to proces, w którym eksperci odgrywają ważną rolę, pomagając w rozwijaniu kompetencji zdrowotnych jednostek i grup społecznych.

Ten fakt ma ważne konsekwencje dla zwalczania infodemii oraz promowania kompetencji zdrowotnych polskich obywateli. Uzyskanie bardziej efektywnego ramowania w tym zakresie możliwe jest poprzez lepsze skoordynowanie form przekazu wiedzy specjalistycznej w różnych mediach tak, aby był on trafnie dobrany do potrzeb grup docelowych. Uderzająca jest bowiem nikła obecność w dyskursie publicznym konceptualizacji metaforycznych dotyczących komunikowania rodzicom/opiekunom sposobów udzielania wsparcia psychicznego dzieciom/nastolatkom. Należy zintensyfikować wysiłki popularyzowania wiedzy eksperckiej na ten temat tak, aby dorośli, którzy sami borykają się z lękiem i depresją, wywołanymi zagrożeniem epidemicznym, byli w stanie przyswoić z dyskursu publicznego wiedzę, rozwijając swoje kompetencje zdrowotne ukierunkowane na pomoc nie tylko sobie, ale i młodym ludziom jako najbardziej wrażliwej grupie społecznej. 
Źródła danych językowych (według daty publikacji)

Dubec, M. i Rymaszewska, J. (2020, 19 marca). Ważne, by znaleźć balans. Pobrano 30 czerwca 2021 z: Wrocław.pl

Mazurek, M. i Dudek, D. (2020, 20 marca). Przechodzimy właśnie przez zbiorową traumę. Pobrano 30 czerwca 2021 z: https://plus.gazetakrakowska.pl

Padoł, E. i Woydyłło, E. (2020, 23 marca). „Dlaczego?” to ulubione pytanie w Polsce. Pobrano 30 czerwca 2021 z: kultura.onet.pl

Górski, P. i Łoza, B. (2020, 25 marca). Załamanie emocji dopiero przed nami. Pobrano 30 czerwca 2021 z: rp.pl

Nowak, T. i Dudek, D. (2020, 2 kwietnia). Plaga wpływa na psychikę. Pobrano 30 czerwca 2021 z: rp.pl

Rymaszewska, J. (2020, 6 kwietnia). Eksperci alarmują: nadchodzi fala załamań psychicznych. Pobrano 30 czerwca 2021 z: PolsatNews.pl

Kurzyńska, E. i Gondek, T. (2020, 17 kwietnia). Skutki pandemii koronawirusa: przewlekły stres uderza nie tylko w psychikę. Pobrano 30 czerwca 2021 z: pulsmedycyny.pl

Sarnat, J. i Wiśniewski, I. (2020, 15 maja). Czego boją się dzieci podczas pandemii koronawirusa? Pobrano 30 czerwca 2021 z: DziennikPolski.pl

Witwicki, P. i Gałecki, P. (2020, 28 maja). Piotr Gałecki: Musieliśmy wybrać, co będzie mniejszym złem. Pobrano 30 czerwca 2021 z: RP.pl

Stanek-Misiąg, E. i Wilanowska-Parda, D. (2020, 22 czerwca). Co pandemia zabrała, a co dała młodym. Pobrano 30 czerwca $2021 \mathrm{z:}$ mp.pl

Żyła, M. i Barbaro, de, N. (2020, 26 października). Życie, teraz. Pobrano 30 czerwca 2021 z: tygodnikpowszechny.pl

Opolska, Z. i Murawiec, S. (2020, 20 listopada). Czy ptaki pomogą nam w dobie koronawirusa? Pobrano 30 czerwca 2021 z: medonet.pl

Apiecionek, K. i Selwant, K. (2020, 1 grudnia). Pandemia jak maraton. Pobrano 30 czerwca 2021 z: radiozet.pl

Kaczmarczyk, E. i Tutko, K. (2020, 14 grudnia). Osoby, które doświadczyły pandemii, mogą przekazywać lęk swoim dzieciom. Pobrano 30 czerwca 2021 z: HelloZdrowie.pl

Hodak, M. i Oberle, A. (2020, 28 grudnia). Planujmy, co zrobimy po pandemii. Pobrano 30 czerwca 2021 z: Pabianice.tv

Müller, M. i Pilecki, M. (2021, 18 stycznia). Kryzys psychiatrii, kryzys młodzieży. Pobrano 30 czerwca 2021 z: tygodnikpowszechny.pl

Wysocka, M. i Minta, D. (2021, 19 stycznia). Pandemia - czy to, co przeżywamy, może skończyć się PTSD? Pobrano 30 czerwca 2021 z: mp.pl

Jarosz, M. i Zydoń, A. (2021, 30 stycznia). Trudny powrót do „dawnego świata”. Pobrano 30 czerwca 2021 z: kobieta.dziennik.pl

Żyła, M. i Latkowska, J. (2021, 22 lutego). Zmęczenie niczym. Trudny powrót do „dawnego świata”. Pobrano 30 czerwca 2021 z: dziennik.pl

Garbacka, J. (2021, 2 marca). Zdrowie psychiczne Polaków w czasach COVID-19. Pobrano 30 czerwca 2021 z: executivemagazine.pl

Frankowska, A. i Rajba, B. (2021, 4 marca). Destrukcyjny wpływ pandemii na naszą psychikę. Pobrano 30 czerwca 2021 z: centrumprasowe.dsw.edu.pl

Marciniak. I. i Giza, E. (2021, 17 marca). Z psychiatrą Ewa Gizą z Kołobrzegu o wpływie pandemii na nasze zdrowie psychiczne. Pobrano 30 czerwca 2021 z: kolobrzeg.naszemiasto.pl

Remberk, B. (2021, 24 marca). Dr B. Remberk m.in. o reformie i skutkach pandemii. Pobrano 30 czerwca 2021 z: politykazdrowotna.com 


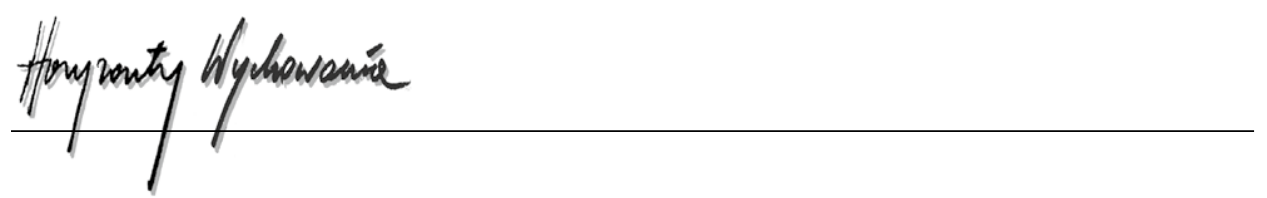

Nowosielska, P. i Szwajca, K. (2021, 26 marca). Dzieci w Polsce są w złej kondycji psychicznej. Pobrano 30 czerwca 2021 z: gazetaprawna.pl

Bekrycht, H. i Koprowicz, J. (2021, 28 marca). Minie lockdown, minie dramat umierających ludzi, a my nie będziemy potrafili normalnie żyć. Pobrano 30 czerwca 2021 z: forsal.pl

Mazurek, R. i Święcicki, Ł. (2021, 2 kwietnia). Część antyszczepionkowców to osoby, które mają urojeniowe podejście do rzeczywistości. Pobrano 30 czerwca 2021 z: rmf.fm

Zięba, S. i Rudnik, A. (2021, 29 kwietnia). Pandemia rujnuje zdrowie psychiczne dzieci. Pobrano 30 czerwca 2021 z: trojmiasto.pl

Kurzyńska, E. i Gondek, T., (2021, 7 maja). COVID-19 wpływa destrukcyjnie na układ nerwowy. Pobrano 30 czerwca 2021 z: puls medycyny.pl

Kallalas, P. i Kaszubowski, T. (2021, 24 maja). Trudna sytuacja psychiatrii. Pobrano 30 czerwca 2021 z: trojmiasto.pl

Ćwiek, J. i Popek, L. (2021, 31 maja). Dzieci często chcą zabić się w maju. Pobrano 30 czerwca 2021 z: RP.pl

Nodzyńska, P. i Żechowski, C. (2021, 2 czerwca). W pandemii wzrosły depresje u dzieci. Moi koledzy już nie dają rady, a problem dopiero narasta. Pobrano 30 czerwca 2021 z: wyborcza.pl

\section{BIBLIOGRAFIA}

Craig, D. (2020). Pandemic and its metaphors: Sontag revisited in the COVID-19 era. European Journal of Cultural Studies, 23(6), 1025-1032. doi.org/10.1177/1367549420938403

Demjén, Z. i Semino, E. (2016). Using metaphor in healthcare. W: Z. Demjén i E. Semino (red.), The Routledge handbook of metaphor and language (s. 385-399). Routledge.

Doroszewska, A., Dudek, D., Jabłoński, M., Kłosińska, K., Murawiec, S. i Sobczak, B. (2021). Wrażliwi na słowa. Wrażliwi na ludzi. Rekomendacje dotyczące języka niedyskryminującego osób z zaburzeniami psychicznymi. Psychiatria, 18(2), 163-167.

Evans, V. (2007). Leksykon językoznawstwa kognitywnego. Universitas.

Gambin, M. (red.). (2021). Pandemia COVID-19 w Polsce. Perspektywa psychologiczna. 24 raporty z badań ekspertów. https://covid.psych.uw.edu.pl/wp-content/uploads/sites/50/2021/03/ raporty-covid-2020.pdf

Gibbs, R. (2016). Metaphor, language, and dynamical systems. W: Z. Demjén i E. Semino (red.), The Routledge handbook of metaphor and language (s. 56-69). Routledge.

Gibbs, R. (2017). Metaphor wars. Cambridge.

Heitzman, J. (2020). Wpływ pandemii COVID-19 na zdrowie psychiczne. Psychiatria Polska, 54(2), 187-198. DOI: https://doi.org/10.12740/PP/120373

Jaspal, R. i Nerlich, B. (2020). Social representations, identity threat, and coping amid COVID-19. Psychological Trauma: Theory, Research, Practice, and Policy, 12(S1), S249-S251. https:// doi.org/10.1037/tra0000773

Kövecses, Z. (2011). Język, umyst, kultura. Praktyczne wprowadzenie (A. Kowalcze-Pawlik i M. Buchta, tłum.). Universitas.

Krawczyk-Wasilewska, V. (2020). COVID-19 jako paradygmat choroby globalnej. Lud, 104, 155-184. http://dx.doi.org/10.12775/lud104.2020.07

Makowska, M. (2021). Język i obraz wobec koronawirusa. Forum Lingwistyczne, 8, 1-14. http:// doi.org/10.31261/FL.2021.08.09

Nutbeam, D. (1998). Health promotion glossary. Health Promotion International, 13(4), 349-364.

Semino, E. (2021). Not Soldiers but Fire-fighters-Metaphors and Covid-19. Health Communication, 36(1), 50-58. DOI: 10.1080/10410236.2020.1844989 
Tay, D. (2016). Using metaphor in healthcare: mental health. W: Z. Demjén i E. Semino (red.), The Routledge handbook of metaphor and language (s. 371-384). Routledge.

Thibodeau, P.H., Hendricks, R.K. i Boroditsky, L. (2017). How linguistic metaphor scaffolds reasoning. Trends in Cognitive Sciences, 21(11), 852-863. https://doi.org/10.1016/j.tics.2017.07.001

Wallis, P. i Nerlich, B. (2005). Disease metaphors in new epidemics: the UK media framing of the 2003 SARS epidemic. Social Science \& Medicine, 60(11), 2629-2639. https://doi.org/10.1016/j. socscimed.2004.11.031

Wicke, P. i Bolognesi, M. (2020). Framing COVID-19: How we conceptualize and discuss the pandemic on Twitter. PLoS ONE, 15(9), e0240010. https://doi.org/10.1371/journal.pone.0240010

Wojtukiewicz, A. (2020). Pandemia COVID-19 - metaforyka w głównych wydaniach polskich dzienników telewizyjnych. com.press, 3(2), 50-67.

Zbróg, Z. i Zbróg, P. (2016). Reprezentacje społeczne jako nośniki pamięci zbiorowej. Horyzonty Wychowania, 15(36), 1127. DOI:10.17399/HW.2016.153601

\section{Copyright and License}

This article is published under the terms of the Creative Commons Attribution - NoDerivs (CC BY- ND 4.0) License http://creativecommons.org/licenses/by-nd/4.0/ 